\title{
SUBSTITUTION OF COAL BY REFUSE DERIVED FUELS (RDF) IN THE PRECALCINER OF A CEMENT KILN SYSTEM
}

\author{
AMILA CHANDRA KAHAWALAGE, MORTEN C. MELAAEN, LARS-ANDRÉ TOKHEIM \\ Department of Process, Energy and Environmental Technology, Faculty of Technology, Natural Sciences and \\ Maritime Sciences, University College of Southeast Norway, 3918, Porsgrunn, Norway
}

\begin{abstract}
Cement manufacturing is an energy intensive process where coal is the main energy source. Replacement of coal with refuse derived fuels (RDF) will reduce costs and $\mathrm{CO}_{2}$ emissions as RDF is partly carbon neutral. In modern cement kilns, most of the calcination $\left(\mathrm{CaCO}_{3}(\mathrm{~s}) \rightarrow \mathrm{CaO}(\mathrm{s})+\mathrm{CO}_{2}\right)$ is carried out in the precalciner, and the process conditions there make it a good reactor for combustion of alternative fuels like RDF. However, most waste-derived fuels have a poorer quality than coal, and this could negatively affect the process. In this study, a model of the calcination and fuel combustion in the precalciner has been developed, and different fuel input cases have been simulated. The results indicate that it is feasible to use RDF to fully replace coal as an energy source in the precalciner. However, to obtain the same degree of calcination, the specific energy consumption will increase by $10 \%$ compared to coal if the RDF moisture content is $25 \%$ (a quite typical value). This is due to the fuel characteristics. As a result of the increased energy consumption, the exhaust gas flow rate also increases. Using RDF with $25 \%$ moisture content increases the exhaust gas volume flow rate from the kiln system by $11 \%$. This is equivalent to a reduction in the production capacity. Considering that waste fuels like RDF are usually less expensive than coal, operating a precalciner with RDF as a coal replacement becomes a trade-off between lower fuel costs and lower production capacity.

Keywords: refuse derived fuels, cement kiln system, precalciner.
\end{abstract}

\section{INTRODUCTION}

\subsection{The cement manufacturing process}

Cement is likely the most used construction material in the world. The typical manufacturing process, which is schematically represented in Fig. 1, starts with mining of limestone and is followed by crushing, adding of additives, grinding, calcining and clinker production. The intermediate product is called "raw meal". A precalciner kiln system was the basis for this study. It normally consists of a preheater, a precalciner (also known as calciner), a rotary kiln and a cooler. The kiln feed (i.e. the raw meal) is heated in the preheater and then sent to the precalciner where typically $85-95 \%$ of the calcination takes place. In the rotary kiln, the remaining calcination is completed and clinker is formed.

\subsection{Energy use and $\mathrm{CO}_{2}$ emissions in the cement industry}

The most commonly used fuel source in the cement industry is coal. Cement manufacturing is an important source of $\mathrm{CO}_{2}$ emissions, which accounted for $1.8 \mathrm{Gt} \mathrm{CO}_{2}$ in 2005 [2]. Nowadays, alternative fuels are becoming more and more common in the cement industry. These fuels are typically derived from industrial and municipal sources, and may be hazardous or non-hazardous waste materials. A detailed description of types and categories of alternative fuels can be found in [3]. Many cement plants are searching for ways to utilize 


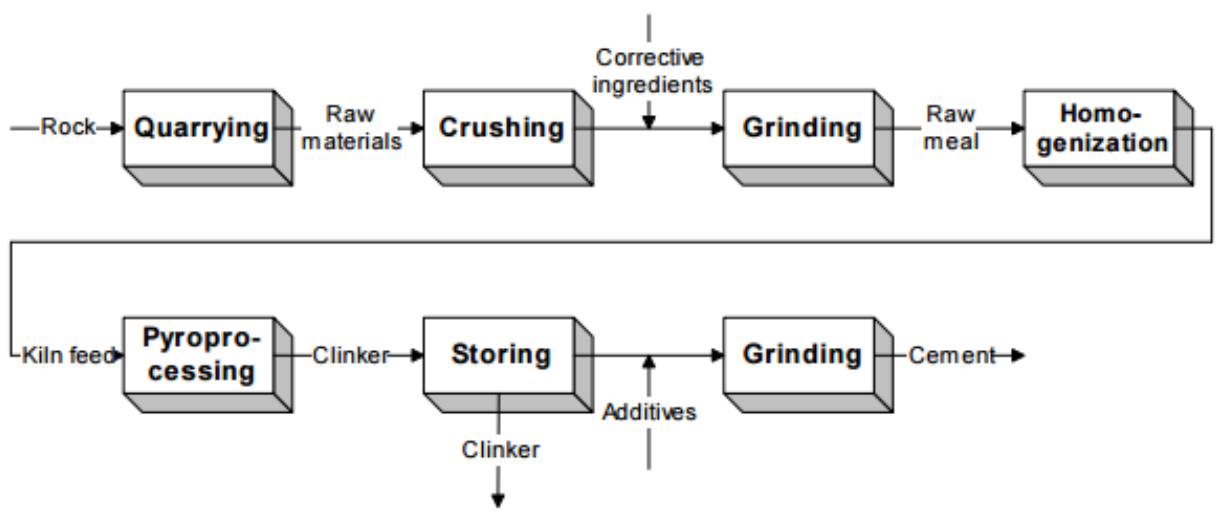

Figure 1: Principal drawing of cement manufacturing process [1].

alternative fuels to fulfill the energy requirement as traditional fossil energy sources are expensive and not environmentally friendly.

\subsection{RDF in the cement industry}

Refuse derived fuels (RDF) is the general term used to describe the shredded or pelletized fraction of municipal solid waste after removing non-combustible materials (glass, metals etc). It consists of different kinds of materials such as paper, cardboard, wood, plastics, textiles and rubber as well as some inorganic materials. RDF is usually a quite inhomogeneous mixture and may have a high content of metallic components [4]. RDF is a partially $\mathrm{CO}_{2}$-neutral fuel as it contains both fossil and biogenic materials [8]. The fossil fraction is typically around $30 \mathrm{wt} \%$.

To supply the required thermal energy in the kiln system, RDF may be burnt in the rotary kiln as well as in the precalciner as a replacement for coal, and would thereby reduce the net $\mathrm{CO}_{2}$ emissions from the plant. The ash, which will contain most of the metals from the RDF, will end up in the clinker and will eventually be stabilized in the concrete [8]. However, there may be some limitations to how much RDF that can be used. Low calorific value, high moisture content and high concentrations of chlorine or other trace substances are some major concerns in this connection. Other studies have shown that burning high amounts of waste fuels in the rotary kiln burner, may reduce the flame temperature and thereby negatively impact the product quality [8]. Such impacts are likely not a problem in the calciner as the temperature there is much lower due to the calcination process. However, increased specific heat consumption due to the RDF fuel characteristics could negatively affect the thermal energy consumption and the production capacity of the kiln system. This aspect has apparently not been covered in the available literature and is the main contribution of the current paper.

\subsection{Objectives}

The objectives of this study are 1) to quantify how replacement of coal by RDF may change the thermal energy consumption, 2) to quantify the impact of RDF moisture content on the 
energy consumption and 3) to determine whether the production capacity may be impacted when replacing coal with RDF. Wood, which is a pure biogenic and $\mathrm{CO}_{2}$-neutral material, is also included in the study for comparison.

\subsection{System description}

The annual production capacity of Norcem plant is about 1.4 Mt of cement (and about 1.05 Mt of clinker). Utilization of alternative fuels was started at Norcem by introducing liquid hazard waste in 1987 and solid hazardous waste in 1994 [5]. Currently about 60\% of the fossil fuel energy has been replaced by alternative fuels. RDF is presently the most utilized alternative fuel at Norcem, amounting to around $80000 \mathrm{t} / \mathrm{y}$, and even higher values are expected in the future. Detailed characteristics of RDF can be found in [3]. As shown in Fig. 2, the precalciner is located between the two preheater towers (string 1 and 2, each having four cyclones in series) and the rotary kiln. There are two points for introduction of fuels to the rotary kiln and the precalciner. The exhaust gas from string 2 is used to dry the raw materials in the raw meal mill, which provides raw meal to both strings. The raw meal is fed at the top of the preheater tower.

\section{METHODOLOGY}

The mass and energy balance analysis was applied to precalciner section only. This section has several inlets that are used to inject raw meal, fuels, combustion air and to introduce rotary kiln exhaust gas. There is one outlet. A schematic diagram for the modelling boundary is shown in Fig. 3, $\dot{m}, T$ and $X$ represent mass flow rate, temperature and mass fraction respectively. The modelling was simplified as described in section 2.1. Section 2.2 and 2.3 give equations that were used in the mass and energy balance. All symbols are defined in the nomenclature. Four fuel types were used in the analysis; coal, dry RDF (having a moisture content of approximately $7 \%$, called RDF 7 ), wet RDF (having a moisture content of $25 \%$, called RDF 25) and wood. Their properties are given in .

\subsection{Model simplifications}

A number of simplifications were made in the current modelling: It was assumed that the combustible fuel fraction (volatiles and char) only contains $\mathrm{C}, \mathrm{H}$ and $\mathrm{O}$. An ultimate analysis of a fuel typically also includes $\mathrm{N}$ and $\mathrm{S}$, but these elements are usually present in low concentrations and do not influence the energy balance significantly. Hence, they are neglected here. It was assumed that fuel is combusted as a one-step reaction producing $\mathrm{CO}_{2}$ and $\mathrm{H}_{2} \mathrm{O}$, and fuel conversion was calculated or defined for different cases. Reaction kinetics were not considered. $\mathrm{CaCO}_{3}$ decomposition was modelled based on a calcination efficiency value, and the chemical kinetics of the $\mathrm{CaCO}_{3}$ decomposition were not considered. As kinetics were not included in the analysis, particle size, particle surface area and particle residence time within the domain were also not considered. False air was assumed to be negligible. Any heat loss to the surroundings, kinetic and potential energy effects were neglected. The specific heat capacity values for different species were calculated as temperature dependent values, however, for $\mathrm{CaCO}_{3}$ a constant value was used. It was assumed that the particle and gas outlet temperatures were the same and the system is at steady-state system. 


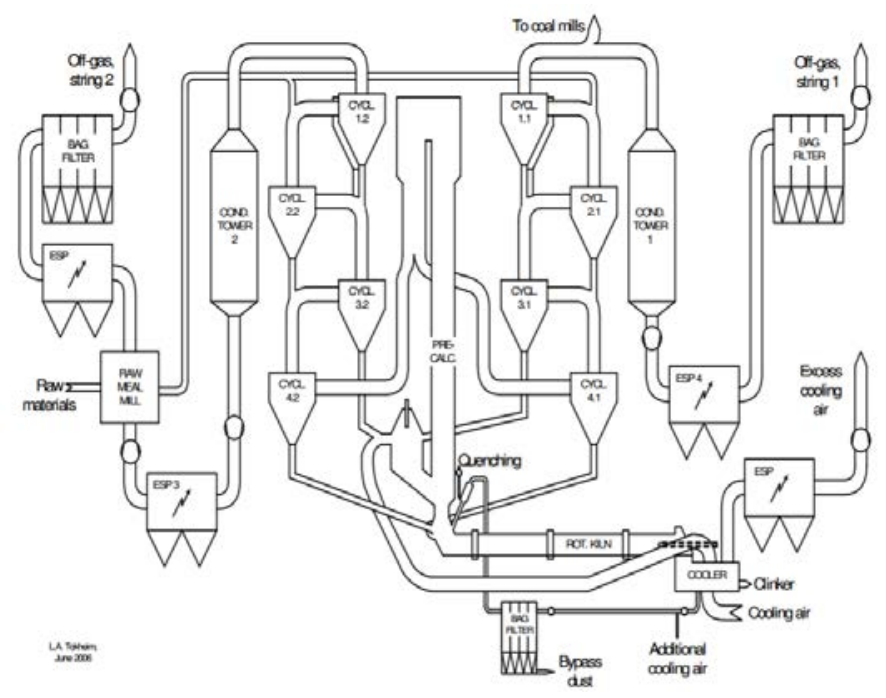

Figure 2: Overview of the precalciner cement kiln system at Norcem Brevik.

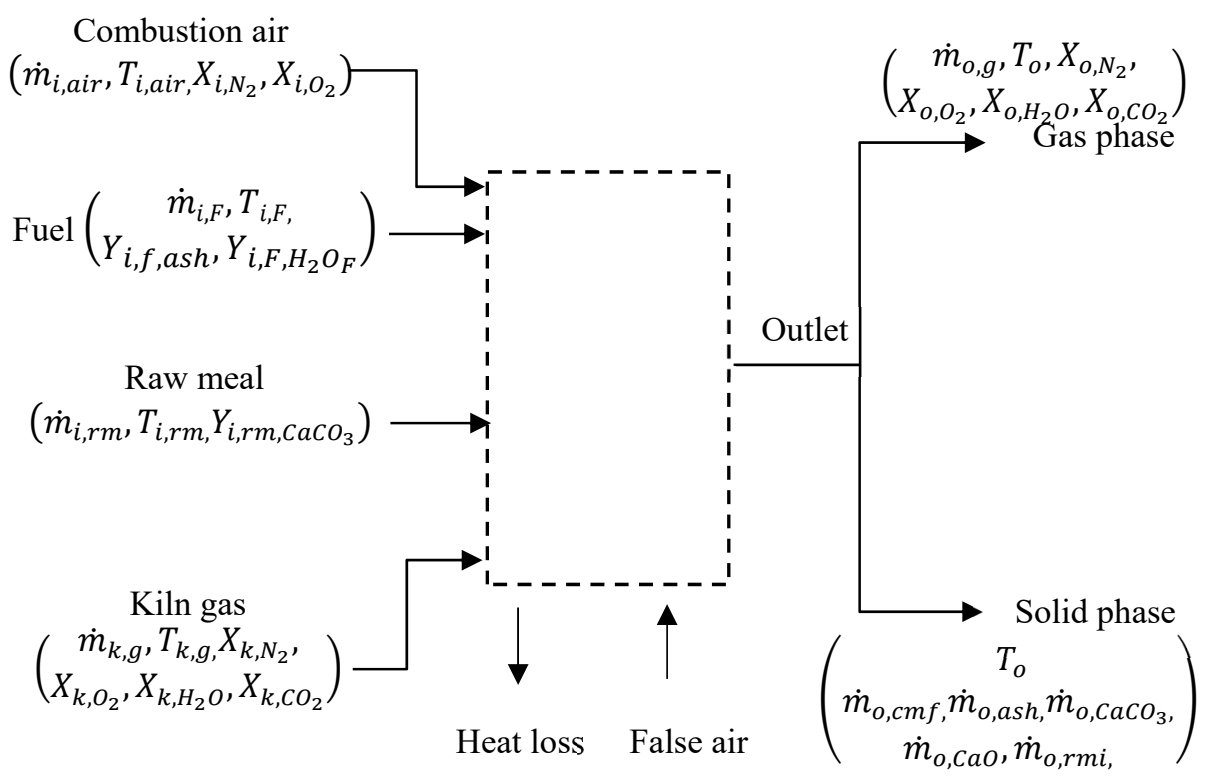

Figure 3: Schematic diagram for modelling boundary. 
Table 1: Fuel properties [8].

\begin{tabular}{|l|c|c|c|c|c|}
\hline Fuel characteristic & Unit & Coal & RDF 7 & RDF 25 & Wood \\
\hline $\mathrm{C}$ & $\mathrm{kg} / \mathrm{kg}$ & 0.729 & 0.431 & 0.348 & 0.448 \\
\hline $\mathrm{H}$ & $\mathrm{kg} / \mathrm{kg}$ & 0.039 & 0.062 & 0.050 & 0.058 \\
\hline $\mathrm{O}$ & $\mathrm{kg} / \mathrm{kg}$ & 0.056 & 0.304 & 0.245 & 0.408 \\
\hline $\mathrm{S}$ & $\mathrm{kg} / \mathrm{kg}$ & 0.014 & 0.004 & 0.003 & 0.002 \\
\hline $\mathrm{N}$ & $\mathrm{kg} / \mathrm{kg}$ & 0.017 & 0.007 & 0.006 & 0.001 \\
\hline Ash & $\mathrm{kg} / \mathrm{kg}$ & 0.136 & 0.121 & 0.098 & 0.006 \\
\hline Moisture & $\mathrm{kg} / \mathrm{kg}$ & 0.01 & 0.071 & 0.25 & 0.077 \\
\hline Lower heating value & $\mathrm{MJ} / \mathrm{kg}$ & 28.3 & 18.2 & 14.2 & 17.0 \\
\hline Energy specific air requirement & $\mathrm{Nm} / \mathrm{MJ}$ & 0.27 & 0.25 & 0.26 & 0.24 \\
\hline
\end{tabular}

\subsection{Mass balance}

When a solid fuel is burnt, the output gas composition is dependent on the chemical composition of the combustible fraction. The empirical molecular formula for the combustible fraction can be taken as $C_{\alpha} H_{\beta} O_{\gamma}$ where $\alpha, \beta$ and $\gamma$ are determined as given in eqns (1)-(3).

$$
\begin{gathered}
\alpha=C \% / M_{C} \\
\beta=H \% / M_{H} \\
\gamma=O \% / M_{O}
\end{gathered}
$$

Eqn (4) represents complete combustion of the fuel.

$$
C_{\alpha} H_{\beta} O_{\gamma}+\left(\frac{2 \alpha+0.5 \beta-\gamma}{2}\right)\left[O_{2}+3.76 N_{2}\right] \rightarrow \alpha . C_{2}+\frac{\beta}{2} H_{2} O+3.76\left(\frac{2 \alpha+0.5 \beta-\gamma}{2}\right) N_{2}
$$

The ratios of $\mathrm{H}_{2} \mathrm{O}$ production:fuel consumption, $\mathrm{CO}_{2}$ production:fuel consumption and $\mathrm{O}_{2}$ consumption:fuel consumption can be calculated using eqns (5), (6) and (7), respectively.

$$
\begin{gathered}
R_{H 2 O / F}=\left(\frac{0.5 \beta M_{H_{2} O}}{M_{F}}\right) \\
R_{C O 2 / F}=\left(\frac{\alpha M_{C O_{2}}}{M_{F}}\right) \\
R_{O 2 / F}=\left(\frac{2 \alpha+0.5 \beta-\gamma}{2 M_{F}}\right) M_{O_{2}}
\end{gathered}
$$

The $\mathrm{CaCO}_{3}$ decomposition can be represented by eqn (8).

$$
\mathrm{CaCO}_{3} \stackrel{\Delta}{\rightarrow} \mathrm{CaO}+\mathrm{CO}_{2}
$$

Specie mass balance for specie $\mathrm{j}$ can be written as in eqn (9)

$$
\frac{d m_{j}}{d t}=\dot{m}_{i, j}+\dot{m}_{k, j}-\dot{m}_{o, j}+\dot{m}_{g, j}
$$

where $\mathrm{j}=\mathrm{N}_{2}, \mathrm{O}_{2}, \mathrm{CO}_{2, k}, \mathrm{H}_{2} \mathrm{O}, \mathrm{CO}_{2, \mathrm{com}}, \mathrm{H}_{2} \mathrm{O}_{\text {g(com) }}, \mathrm{CO}_{2(\mathrm{cal})}$, ash, $\mathrm{cmf}$, rmi, $\mathrm{CaCO}_{3}, \mathrm{CaO}$. 
At steady state $\frac{d m_{j}}{d t}=0$, so then eqn (9) can be simplied as shown in eqn (10).

$$
\dot{m}_{o, j}=\dot{m}_{i, j}+\dot{m}_{k, j}+\dot{m}_{g, j}
$$

\subsection{Energy balance}

The general energy balance can be written as:

$$
\frac{d(H-p V)}{d t}=\dot{H}_{i}+\dot{H}_{k}-\dot{H}_{o}+\dot{W}_{f}+Q
$$

At steady state, adiabatic conditions and without frictional forces eqn (11) turn into eqn (12).

$$
\begin{gathered}
\dot{H}_{i}+\dot{H}_{k}=\dot{H}_{o} \\
H_{i}=\sum_{X} \dot{m}_{i, X}\left(h_{f, X}+c_{p, X, T_{i, X}} T_{i, X}-c_{p, X, T r} T_{r}\right)+h_{f, c m f}\left(\dot{m}_{o, c m f}+\eta_{c o m} \dot{m}_{i, c m f}\right)+ \\
\dot{m}_{i, c m f}\left(c_{p, c m f, T_{i, c m f}} T_{i, c m f}-c_{p, c m f, T_{r}} \mathrm{~T}_{r}\right)
\end{gathered}
$$

where $\mathrm{X}=\mathrm{N}_{2}, \mathrm{O}_{2}, \mathrm{H}_{2} \mathrm{O}_{F}$, ash, $r m i, \mathrm{CaCO}_{3}$

$$
\begin{gathered}
H_{k}=\sum_{U} \dot{m}_{k, U}\left(h_{f, U}+c_{p, U, T_{k, U}} T_{k, U}-c_{p, U, T_{r}} T_{r}\right) \\
\text { where } ; U=N_{2}, O_{2}, H_{2} O_{g}, C O_{2} \\
H_{o}=\sum_{Y} \dot{m}_{o, Y}\left(h_{f, Y}+c_{p, Y, T_{o}} T_{o}-c_{p, Y, T_{r}} T_{r}\right)+\dot{m}_{o, c m f}\left(c_{p, c m f, T_{o}} T_{o}-c_{p, c m f, T_{r}} T_{r}\right) \\
+\dot{m}_{o, c m f} h_{f, c m f}+\dot{m}_{o, C O_{2, c o m}}\left(c_{p, C O_{2, c o m}, T_{o}} T_{o}-c_{p, O_{2, c o m}, T_{r}} T_{r}\right) \\
+\dot{m}_{o, H_{2} O_{c o m(g)}}\left(c_{p, H_{2} O_{c o m(g),} T_{o}} T_{o}-c_{p, H_{2} O_{c o m}(g), T_{r}} T_{r}\right)+\dot{m}_{o, C O_{2, c o m}} h_{f, \mathrm{CO}_{2}} \\
+\dot{m}_{o, H_{2} O_{c o m(g)}} h_{f, H_{2} O(g),}
\end{gathered}
$$

where $\mathrm{Y}=\mathrm{N}_{2}, \mathrm{O}_{2}, \mathrm{CO}_{2}, \mathrm{H}_{2} \mathrm{O}, \mathrm{CO}_{2(\mathrm{cal})}$, ash, $\mathrm{rmi}, \mathrm{CaCO}_{3}, \mathrm{CaO}$

$$
\eta_{c o m} \dot{m}_{i, \mathrm{cmf}} N C V_{D A F}=\eta_{c o m} \dot{m}_{i, \mathrm{cmf}} h_{f, \mathrm{cmf}}-\left(\dot{m}_{o, C \mathrm{C}_{2, \mathrm{com}}} h_{f, \mathrm{CO}_{2}}+\dot{m}_{o \mathrm{H}_{2} \mathrm{O}_{c o m(g)}} h_{f, H_{2} \mathrm{O}(\mathrm{g})}\right) \text {. }
$$

\subsection{Boundary conditions}

To be able to carry out the mass and energy balance analysis, boundary conditions are required, and these are presented in . The kiln gas composition can be considered quite typical for a precalciner kiln system.

Table 2: Boundary conditions in the combustion air, kiln gas, raw meal and exhaust gas. 


\begin{tabular}{|l|c|c|}
\hline Parameter (symbol) & Unit & Value \\
\hline Combustion air temperature $\left(\mathrm{T}_{\mathrm{i}, \text { air }}\right)$ & ${ }^{\circ} \mathrm{C}$ & 800 \\
\hline Combustion air $\mathrm{N}_{2}$ mass fraction $\left(\mathrm{X}_{\mathrm{i}, \mathrm{N}_{2}}\right)$ & $\mathrm{kg} / \mathrm{kg}$ & 0.767 \\
\hline Combustion air $\mathrm{O}_{2}$ mass fraction $\left(\mathrm{X}_{\mathrm{i}, \mathrm{O}_{2}}\right)$ & $\mathrm{kg} / \mathrm{kg}$ & 0.233 \\
\hline Kiln gas mass flow rate $\left(\dot{\mathrm{m}}_{\mathrm{k}, \mathrm{g}}\right)$ & $\mathrm{kg} / \mathrm{s}$ & 30 \\
\hline Kiln gas temperature $\left(\mathrm{T}_{\mathrm{k}, \mathrm{g}}\right)$ & ${ }^{\circ} \mathrm{C}$ & 1050 \\
\hline Kiln gas $\mathrm{N}_{2}$ mass fraction $\left(\mathrm{X}_{\mathrm{k}, \mathrm{N}_{2}}\right)$ & $\mathrm{kg} / \mathrm{kg}$ & 0.697 \\
\hline Kiln gas $\mathrm{O}_{2}$ mass fraction $\left(\mathrm{X}_{\mathrm{k}, \mathrm{O}_{2}}\right)$ & $\mathrm{kg} / \mathrm{kg}$ & 0.081 \\
\hline Kiln gas $\mathrm{H}_{2} \mathrm{O}$ mass fraction $\left(\mathrm{X}_{\mathrm{k}, \mathrm{H}_{2} \mathrm{O}}\right)$ & $\mathrm{kg} / \mathrm{kg}$ & 0.031 \\
\hline Kiln gas $\mathrm{CO}_{2}$ mass fraction $\left(\mathrm{X}_{\mathrm{k}, \mathrm{CO}_{2}}\right)$ & $\mathrm{kg} / \mathrm{kg}$ & 0.191 \\
\hline Raw meal mass flow rate $\left(\dot{\mathrm{m}}_{\mathrm{i}, \mathrm{rm}}\right)$ & $\mathrm{kg} / \mathrm{s}$ & 64 \\
\hline Raw meal temperature at inlet $\left(\mathrm{T}_{\mathrm{i}, \mathrm{rm}}\right)$ & ${ }^{\circ} \mathrm{C}$ & 800 \\
\hline Raw meal CaCO 3 mass fraction at inlet $\left(\mathrm{Y}_{\mathrm{i}, \mathrm{rm}, \mathrm{CaCO}_{3}}\right)$ & $\mathrm{kg} / \mathrm{kg}$ & 0.8 \\
\hline Exhaust gas $\mathrm{O}_{2}$ mole fraction $\left(\mathrm{x}_{\mathrm{0}, \mathrm{O}_{2}}\right)$ & $\mathrm{mol} / \mathrm{mol}$ & 0.04 \\
\hline
\end{tabular}

\subsection{Case definitions}

A number of calculation cases were defined. The first group of cases is presented in. Coal was taken as the reference fuel in Case 1-1, and the fuel input required to obtain $85 \%$ calcination degree and $880^{\circ} \mathrm{C}$ product temperature, and the air input required to obtain 4 vol $\% \mathrm{O}_{2}$ in the exit gas (boundary condition in Table 2), were then calculated. The resulting exit gas composition was also calculated. The same fuel energy input was then applied in the next three cases, i.e. Case 1-2 (dry RDF), Case 1-3 (wet RDF) and Case 1-4 (wood). The calcination degree was then calculated for these three cases assuming the same outlet temperature and complete combustion of the fuel. The purpose was to investigate how different fuel characteristics impact the calcination degree, exhaust gas composition and flow rate.

Table 3: Simulation cases defined for constant fuel energy input and outlet temperature.

\begin{tabular}{|l|c|c|c|c|}
\hline Parameter & Case 1-1 & Case 1-2 & Case 1-3 & Case 1-4 \\
\hline Fuel type & Coal & RDF 7 & RDF 25 & Wood \\
\hline $\begin{array}{l}\text { Outlet } \\
\text { temperature }\end{array}$ & $880^{\circ} \mathrm{C}$ & $880^{\circ} \mathrm{C}$ & $880^{\circ} \mathrm{C}$ & $880^{\circ} \mathrm{C}$ \\
\hline $\begin{array}{l}\text { Calcination } \\
\text { degree }\end{array}$ & $85 \%$ & To be calculated & To be calculated & To be calculated \\
\hline Fuel conversion & $100 \%$ & $100 \%$ & $100 \%$ & $100 \%$ \\
\hline Fuel energy & Calculated & $\begin{array}{c}\text { Same as in } \\
\text { Case } 1.1\end{array}$ & $\begin{array}{c}\text { Same as in } \\
\text { Case } 1.1\end{array}$ & $\begin{array}{c}\text { Same as in } \\
\text { Case } 1.1\end{array}$ \\
\hline $\begin{array}{l}\text { Combustion air } \\
\text { flow rate }\end{array}$ & Calculated & Calculated & Calculated & Calculated \\
\hline $\begin{array}{l}\text { Exhaust gas flow } \\
\text { rate and } \\
\text { composition }\end{array}$ & Calculated & Calculated & Calculated & Calculated \\
\hline
\end{tabular}


Table 4: Simulation cases defined*.

\begin{tabular}{|l|l|l|l|l|}
\hline Parameter & Case 2-1 & Case 2-2 & Case 2-3 & Case 3 \\
\hline Fuel type & RDF 7 & RDF 25 & Wood & RDF 25 \\
\hline Outlet temperature & $880^{\circ} \mathrm{C}$ & $880^{\circ} \mathrm{C}$ & $880^{\circ} \mathrm{C}$ & $880^{\circ} \mathrm{C}$ \\
\hline Calcination degree & $85 \%$ & $85 \%$ & $85 \%$ & $85 \%$ \\
\hline Fuel conversion & $100 \%$ & $100 \%$ & $100 \%$ & $100 \%$ \\
\hline $\begin{array}{l}\text { Exhaust gas flow } \\
\text { rate }\end{array}$ & Calculated & Calculated & Calculated & $\begin{array}{l}\text { Same as in Case } \\
1-1\end{array}$ \\
\hline Fuel energy & Calculated & Calculated & Calculated & Calculated \\
\hline $\begin{array}{l}\text { Combustion air flow } \\
\text { rate }\end{array}$ & Calculated & Calculated & Calculated & Calculated \\
\hline $\begin{array}{l}\text { Exhaust gas } \\
\text { composition }\end{array}$ & Calculated & Calculated & Calculated & Calculated \\
\hline
\end{tabular}

${ }^{*}$ For constant calcination degree and outlet temperature for Case 2-1, 2-2 and 2-3 and for constant calcination degree, outlet temperature and exit gas flow rate for Case 3.

Table 5: Calculation algorithm for Method 1 and Method 2.

\begin{tabular}{|c|c|c|}
\hline \multirow[t]{2}{*}{ Step No } & \multicolumn{2}{|c|}{ Method } \\
\hline & Method 01 & Method 02 \\
\hline 01 & Guess $\dot{m}_{f u e l}$ & Define fuel energy and calculate $\dot{m}_{f u e l}$ \\
\hline 02 & Guess $\dot{m}_{\text {air }}$ & Guess $\eta_{\text {cal }}$ \\
\hline 03 & Define required $\eta_{\text {com }}$ & Guess $\dot{m}_{\text {air }}$ \\
\hline 04 & Define required $x_{o, O 2}$ & Define required $x_{o, O 2}$ \\
\hline 05 & Define required $\eta_{c a l}$ & Define required $\eta_{\text {com }}$ \\
\hline 06 & Define required $T_{o, j}$ & Define required $T_{o, j}$ \\
\hline 07 & Calculate all $\dot{m}_{o, j}$ & Calculate all $\dot{m}_{o, j}$ \\
\hline 08 & Calculate $x_{o, O 2}$ & Calculate $x_{0, O 2}$ \\
\hline 09 & ${ }^{*}$ Calculate $E x_{0,02}$ & ${ }^{*}$ Calculate $E x_{o, O 2}$ \\
\hline 10 & $\begin{array}{l}{ }^{* *} \text { If } ; E x_{o, O 2} \leq \Delta_{E x_{o, O 2}} \\
\text { Go to Step } 11 \text { otherwise go to step } 02\end{array}$ & $\begin{array}{l}{ }^{* *} \text { If } ; E x_{o, O 2} \leq \Delta_{E x_{o, O 2}} \\
\text { Go to Step } 11 \text { otherwise go to step } 03\end{array}$ \\
\hline 11 & Calculate actual $\eta_{\text {com }}$ by solving eqn (11-16) & Calculate actual $\eta_{\text {cal }}$ by solving eqn (11-16) \\
\hline 12 & ${ }^{+}$Calculate $E \eta_{\text {com }}$ & ${ }^{\times}$Calculate $E \eta_{\text {cal }}$ \\
\hline 13 & $\begin{array}{l}{ }^{++} \text {If } ; E \eta_{\text {com }} \leq \Delta_{E \eta_{\text {com }}} \\
\text { Go to Step } 14 \text { otherwise go to step } 01\end{array}$ & $\begin{array}{l}{ }^{\mathrm{x}} \text { If } ; E \eta_{c a l} \leq \Delta_{E \eta_{c a l}} \\
\text { Go to Step } 14 \text { otherwise go to step } 02\end{array}$ \\
\hline 14 & $\begin{array}{l}\text { Calculated required fuel energy, air } \\
\text { requirement and outlet gas composition }\end{array}$ & $\begin{array}{l}\text { Calculated maximum } \mathrm{CaCO}_{3} \text { conversion, } \\
\text { air requirement and outlet gas composition }\end{array}$ \\
\hline \multicolumn{3}{|c|}{$\begin{array}{l}{ }^{*} E x_{o, O 2} \text { refers to the difference between calculated and required oxygen composition }{ }^{* *} \Delta_{E x_{o, O 2}} \text { refers to the maximum } \\
\text { possible error based on difference between calculated and required oxygen composition in this analysis to terminate } \\
\text { iteration. } \\
{ }^{+} E \eta_{c o m} \text { refers to the combustion efficiency difference between calculated and required } ;{ }^{++} \Delta_{E \eta_{c o m}} \text { refers to the } \\
\text { maximum possible combustion efficiency error based on difference between calculated and required in this analysis } \\
\text { to terminate iteration. } \\
\times E \eta_{c a l} \text { refers to the calcination degree difference between calculated and required } ;{ }^{\times \times} \Delta_{E \eta_{c a l}} \text { refers to the maximum } \\
\text { possible calcination degree error based on difference between calculated and required in this analysis to terminate } \\
\text { iteration. }\end{array}$} \\
\hline
\end{tabular}

The next group of cases is presented in . Now the same calcination degree (85\%) and the outlet temperature $\left(880^{\circ} \mathrm{C}\right)$ were required to be the same as in Case $1-1$, and instead the fuel feed rate was increased in order to obtain this for dry RDF (Case 2-1), wet RDF (Case 2-2) and wood (Case 2-3). The purpose was to investigate how different fuel characteristics impact the fuel energy required to obtain the same conversions as for the coal case (Case 1- 
1), and also how the exhaust gas flow rate and composition is affected by this. Finally, in Case 3, the same calcination degree, outlet temperature and gas flow rate as in the coal case (Case 1-1) were required for the wet RDF, as seen in . To obtain this, the raw meal feed rate had to be reduced, and this reduction corresponds to a reduction in production capacity. The idea of running this case is that for a given kiln system, the exit gas flow rate can often be considered a bottleneck in the production line. Hence, the purpose was to investigate the impact on the production capacity while otherwise keeping process conditions more or less constant.

\subsection{Calculation algorithms}

Two different calculation algorithms were used, and these are shown in . Method 1 was used for Case 1.1, 2.1, 2.2 and 2.3, while Method 2 was used for case 1.2, 1.3 and 1.4. For case 3, a trial-and-error method was used. These algorithms were implemented in Matlab R2016 b, a matrix-based commercial calculation software tool.

\section{RESULTS AND DISCUSSION}

Fig. 4 and Fig. 5 show results for Case 1-1, 1-2, 1-3 and 1-4, while Fig. 6 and Fig. 7 show results for Case 1-1, 2-1, 2-2, 2-3 and 3. According to Fig. 4 and Table 1 the calcination degree decreases when the RDF moisture content increases. The calcination degree of the wood case is higher than that of RDF 25, but less than that of coal. This is the case even if the energy supply is the same in all cases, but can be explained by the fuel characteristics. As seen in , the energy specific air requirement $\left[\mathrm{Nm}^{3} / \mathrm{MJ}\right]$ is a bit higher for coal than for burning coal, and this could indicate a less efficient calcination process. However, this energyspecific air demand effect is more than outweighed by another effect. The higher moisture content in the waste fuels increases the moisture content in the exhaust gas, as seen in Fig. 5, meaning that more energy must be spent on heating water vapour in Case 1-2, 1-3 and 1-4. This reduces the energy portion spent on calcination. RDF 25 has the highest sensible heat contribution and the lowest calcination degree due to the high moisture content the waste fuels.

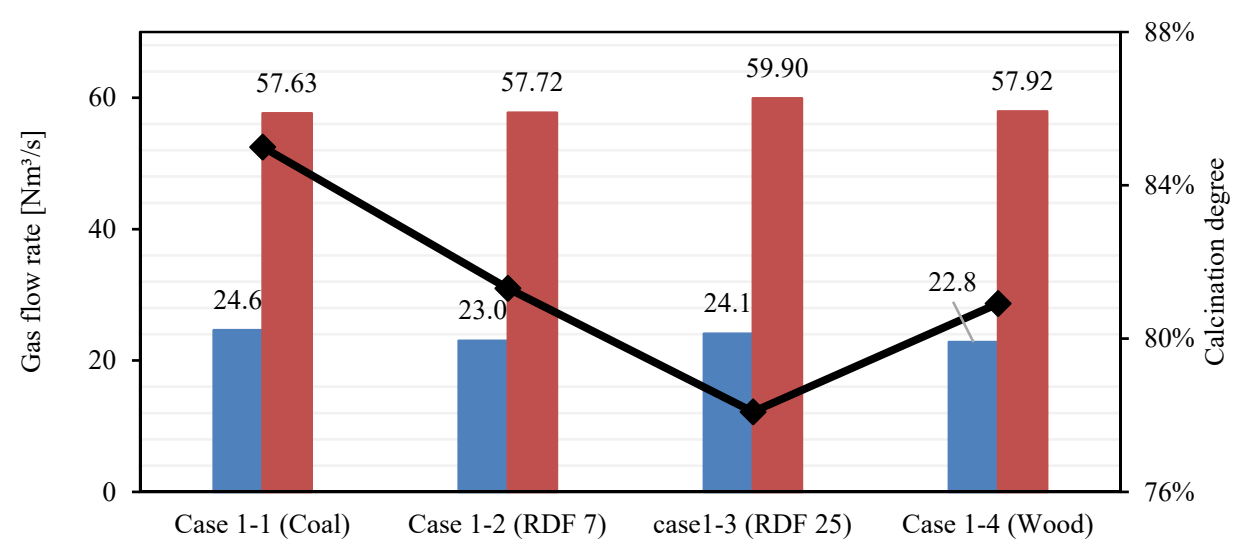

Combustion air flow rate $[\mathrm{Nm} 3 / \mathrm{s}] \longrightarrow$ Exhaust gas flow rate $\left[\mathrm{Nm}^{3} / \mathrm{s}\right] \longrightarrow$ Calcination degree [-]

Figure 4: Calculated gas flow rate and calcination degree for Case 1 analysis. 


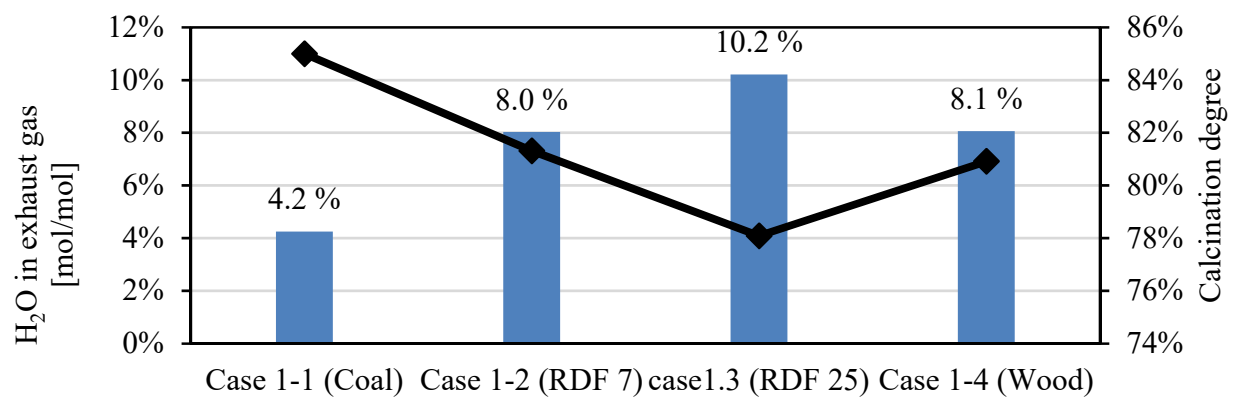

$\mathrm{H} 2 \mathrm{O}$ in exhaust gas [mol/mol] $\longrightarrow$ Calcination degree [-]

Figure 5: Calculated moisture content in exhaust gas and calcination degree for Case 1 analysis.

This means that a bit more nitrogen must be heated per energy unit when in this fuel. The ash content also makes an impact, as also the ash must be heated to the product temperature, but this impact is smaller than that of the moisture.

To achieve the required calcination degree (which impacts the product quality) and outlet temperature, the fuel energy supply should be increased in the alternative fuel cases, as explained above. The required fuel energy values in Case 2-1, 2-2 and 2-3 are compared with that of Case 1-1 in Fig. 6. RDF 25 has the highest fuel energy input, and coal the lowest value. The RDF 7 and wood fuel energy supply values are lower than that of RDF 25. This is mainly due to the moisture content of the different waste fuels, and is in line with the discussion in the previous paragraph. An increase in the fuel energy input gives an increase in the combustion air requirement and hence also in the exhaust gas flow rate, as shown in Fig. 7. The exhaust gas flow rate can be seen as a bottleneck in the present precalciner kiln system, i.e. there is basically no room for increasing the exhaust gas flow rate. If the exhaust gas flow rate is assumed to be directly proportional to clinker production rate, the increase in exhaust gas flow rate from about $58 \mathrm{Nm}^{3} / \mathrm{s}$ (Case 1-1; coal) to about $64 \mathrm{Nm}^{3} / \mathrm{s}$ (Case 1-3; wet RDF) roughly corresponds to a production decrease of $11 \%$.

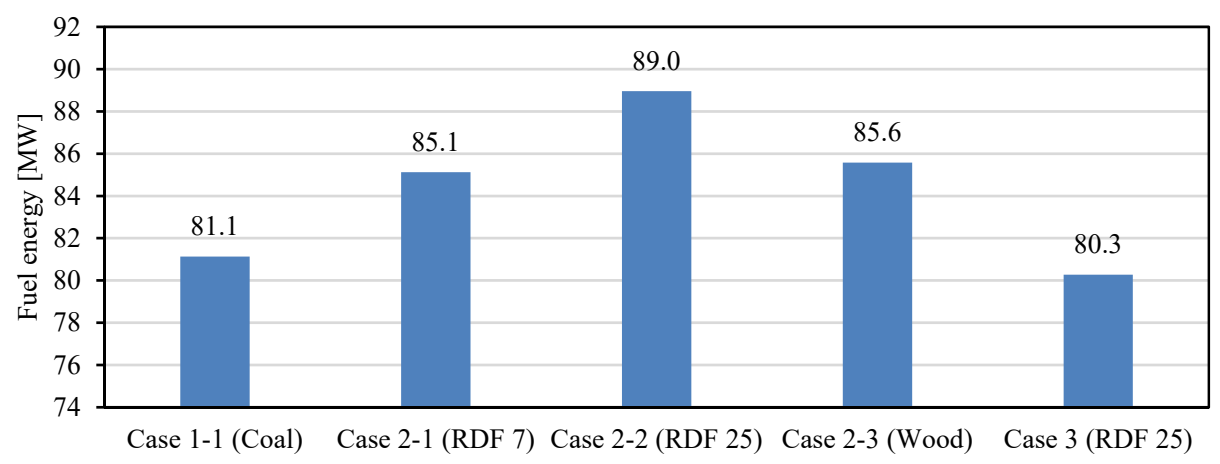

Figure 6: Comparison of calculated fuel energy in Case 2 and Case 3 with respect to Case 1-1. 


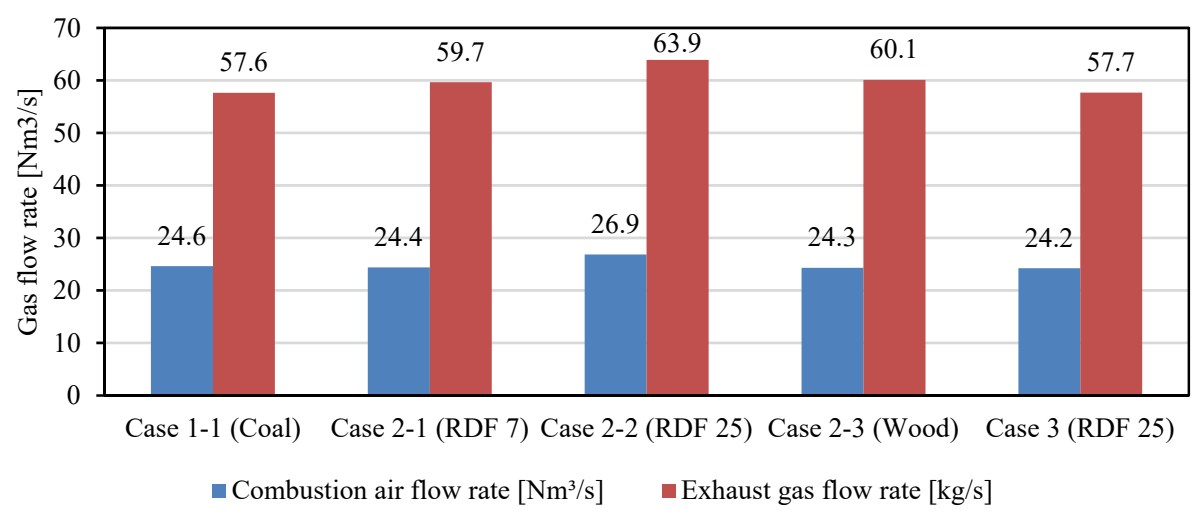

Figure 7: Comparison of combustion air flow rate and exhaust gas flow rate in Case 2 and Case 3 with respect to Case 1-1.

One way to counteract the significant increase in exhaust gas flow rate for the RDF 25 case, could be to pre-dry the wet RDF (which is the more common fuel type at the plant) down to a low value characteristic of a dry RDF, i.e. from 25 to $7 \%$ moisture content. The effect of this is clearly seen by comparing those two RDF qualities in Figs 47. After pre-drying, the drop in production rate will be reduced to only $3 \%$, which may be seen as acceptable considering that coal is entirely replaced by RDF.

Considering that waste fuels like RDF are usually less expensive than coal, operating the precalciner with RDF as a coal replacement can be seen as a tradeoff between lower fuel costs and lower production capacity.

\section{CONCLUSION}

In this study, a model of the calcination and fuel combustion in the precalciner has been developed, and different fuel input cases have been simulated to investigate their impact on the process. The results indicate that even though it is theoretically feasible to use RDF to fully replace coal as an energy source in the precalciner, there are practical limitations. RDF has a higher moisture content and a lower heating value than coal, resulting in a higher exhaust gas flow rate for a given clinker production rate. This is likely to lead to reduced clinker production rates. However, by pre-drying the RDF, possibly using waste-heat from other parts of the cement plant, the negative effect can be counteracted. Considering that waste fuels like RDF are usually less expensive than coal, operating a precalciner with RDF as a coal replacement becomes a tradeoff between lower fuel costs and lower production capacity.

\section{NOMENCLATURE}

$\begin{array}{clll}\dot{m} & \text { Mass flowrate }(\mathrm{kg} / \mathrm{s}) & R_{\mathrm{H} 2 \mathrm{O} / \mathrm{F}} & \begin{array}{l}\text { Ratio of } \mathrm{H}_{2} \mathrm{O} \text { production to fuel } \\ \text { consumption }\end{array} \\ T_{i, \text { air }} \quad \text { Combustion air temperature }\left({ }^{\circ} \mathrm{C}\right) & R_{\mathrm{CO} 2 / \mathrm{F}} & \begin{array}{l}\text { Ratio of } \mathrm{CO}_{2} \text { production to fuel } \\ \text { consumption }\end{array}\end{array}$




$\begin{array}{cl}T_{k} & \text { Kiln gas temperature }\left({ }^{\circ} \mathrm{C}\right) \\ T_{i, F} & \text { Fuel temperature at inlet }\left({ }^{\circ} \mathrm{C}\right) \\ T_{i, r m} & \text { Raw meal temperature at inlet }\left({ }^{\circ} \mathrm{C}\right) \\ X & \text { Gas phase mass fraction } \\ \mathrm{Y} & \text { Solid phase mass fraction }\end{array}$

$M_{F} \quad$ Molecular weight of fuel $c_{p, X, T_{i, X}}$ combustible fraction

$x \quad$ Gas phase mole fraction

$C \%$ Carbon mass percentage of fuel $c_{p, Y, T_{0}}$ combustible fraction

$H \% \quad$ Hydrogen mass percentage of fuel combustible fraction

$0 \%$ Oxygen mass percentage of fuel combustible fraction

$M_{C} \quad$ Molecular weight of C $(\mathrm{g} / \mathrm{mol})$

$M_{H} \quad$ Molecular weight of $\mathrm{H}(\mathrm{g} / \mathrm{mol})$

$M_{O} \quad$ Molecular weight of $\mathrm{O}(\mathrm{g} / \mathrm{mol})$
$\begin{array}{cl}R_{O 2 / F} & \text { Ration of } \mathrm{O}_{2} \text { consumption to } \\ & \text { fuel consumption } \\ \dot{H}_{i} & \text { Sum of the enthalpies at inlet } \mathrm{i}\end{array}$ (W)

$\dot{H}_{k} \quad$ Sum of the enthalpies at inlet k (W)

$\dot{H}_{o} \quad$ Sum of the enthalpies at outlet o (W)

$h_{f, j} \quad$ Standard formation enthalpy of $\mathrm{j}^{\text {th }}$ component $(\mathrm{J} / \mathrm{kg})$

Heat capacity value of $\mathrm{X}$ at $\mathrm{T}_{\mathrm{i}}$ temperature $(\mathrm{J} / \mathrm{kg} / \mathrm{K})$

$c_{p, Y, T_{o}}$

Heat capacity value of $Y$ at $T_{0}$ temperature $(\mathrm{J} / \mathrm{kg} / \mathrm{K})$

$c_{p, U, T_{k, U}}$ Heat capacity value of $\mathrm{U}$ at $\mathrm{T}_{\mathrm{k}}$ temperature $(\mathrm{J} / \mathrm{kg} / \mathrm{K})$

$c_{p, j, T r}$ Heat capacity value of $\mathrm{j}$ at $\mathrm{T}_{\mathrm{r}}$ temperature $\quad(\operatorname{Tr}=298 \quad \mathrm{~K})$ $(\mathrm{J} / \mathrm{kg} / \mathrm{K})$

$\eta_{\text {com }}$ Combustion efficiency

$\eta_{\text {cal }} \quad$ Calcination degree

$N C V_{D A}$. Net calorific value (dry ash free basis) $(\mathrm{J} / \mathrm{kg})$

\author{
ash Fuel ash \\ cmf Fuel combustible part (volatiles \\ and char) \\ F $\quad$ Fuel \\ com Combustion product \\ cal Calcination product
}

\section{ACKNOWLEDGEMENTS}

We are grateful to Ida Husum at Norcem AS Brevik, who provided process and quality data from the plant. Financial support from Telemark Fylkeskommune is greatly acknowledged, as is the support from the Norwegian Research Council through the project "Optimised and increased use of Refuse Derived Fuel as substitute for coal at Norcem Brevik cement plant" (BIA project 245690).

\section{REFERENCES}

[1] Tokheim, L.A., The impact of staged combustion on the operation of a precalciner cement kiln PhD thesis: Telemark College, Norway; 1999.

[2] IEA., Tracking industrial energy efficiency and CO2 emissions : In support of the G8 Plan of Action. France: International Energy Agency, 2007. 
[3] Ariyaratne, W.K.H., Alternative fuels in cement kilns - characterization and experiments Master thesis. Porsgrunn: Telemark University College, Norway; 2009.

[4] Genon, G. \& Brizio, E., Perspectives and limits for cement kilns as a destination for RDF. Waste Management, 28, pp. 2375-85, 2008.

[5] Tokheim, L.A., Gautestad, T., Axelsen E.P. \& Bjerketvedt, D., Energy recovery from wastes : experience with solid alternative fuels combustion in a precalciner cement kiln. International Symposium on Incineration and Flue Gas Treatment Technologies; Brussels, 2001.

[6] Tokheim, L.A., An alternative solution. World Cement, 22(11), pp. 57-63.2005.

[7] Tokheim L. A., Burning chamber installation for increased use of alternative fuels at Norcem Brevik, Norway. 7th International KHD Humboldt Wedag Symposium. Cologne, Germany, 2006.

[8] Ariyaratne, W.K.H., Utilization of Waste-derived Biofuels and Partly $\mathrm{CO}_{2}$-neutral Fuels in Cement Kilns, PhD thesis. Porsgrunn: Telemark University College, 2014. 